\title{
Sensitisation pattern to birch pollen allergen components in oral allergy syndrome to Rosaceae fruits in patients with spring pollinosis from an East European Sylvosteppe area with low density forests
}

\author{
Mariana Vieru ${ }^{1 *}$, Florin-Dan Popescu ${ }^{1}$, Adriana Tudose ${ }^{2}$, Nicolae Dumitrescu ${ }^{3}$ \\ From 5th International Symposium on Molecular Allergology (ISMA 2013) \\ Vienna, Austria. 6-7 December 2013
}

\section{Background}

The cross-reactive molecular allergen components involved in birch pollen-food syndrome depend of the type of food, severity of the food allergic reaction, patient age and the geographic environment, including climate and presence of Fagales-endemic areas.

\begin{abstract}
Methods
We evaluated subjects from Southern Romania, a Central European region with temperate continental climate with submediterranean and humid subtropical influences, where sensitization to Betulaceae pollen is less important in pollinosis compared with that to grass or weed pollen. We selected adult patients from the region of sylvosteppe with low density forests dominated by deciduous species, presenting symptoms of rhinoconjunctivitis in March to May and oral allergy syndrome to fresh Rosaceae fruits, allergic reactions in the mouth and throat without systemic symptoms, and having positive skin prick tests to Betulaceae tree pollen and positive prick-to-prick skin tests with fresh intact and unpeeled apple, pear, apricot, peach, cherry or plum. Because allergen components present in Fagales tree pollen and Rosaceae fruits are PR-10 proteins, profilins and isoflavone reductases, we measured the serum levels of specific IgE to European birch pollen and to recombinant allergen components Bet v1 (birch major PR-10
\end{abstract}

\footnotetext{
"University of Medicine and Pharmacy"Carol Davila", Hospital "Nicolae Malaxa", Department of Allergology and Clinical Immunology, Bucharest, Romania

Full list of author information is available at the end of the article
}

allergen with ribonuclease activity), Bet v2 (birch-pollen profilin), and Bet v6 (birch-pollen isoflavone reductase), using a multiparameter immunoblot test system based on single purified allergen components (SPAC 1).

\section{Results}

Only a case series of four adult spring pollinosis patients with oral allergy syndrome to fresh apple, pear, peach or plum, was detected, and all had specific IgE against rBet $\mathrm{v}$ 1 (genuine sensitization to birch pollen). This is important because Bet $\mathrm{v} 1$ homologues are also found in Rosaceae fruits (PR-10 proteins with $50-60 \%$ identity to Bet $\mathrm{v} 1$ ). Measured levels of serum specific IgE to rBet $v 1$ varied between 30 to $49 \mathrm{kU} / \mathrm{L}$. Specific IgE againts rBet $\mathrm{v} 2$, profilin sensitization marker, $\mathrm{rBet} \mathrm{v} 4$, polcalcin sensitisation marker, and rBet $\mathrm{v} 6$, assessing sensitization to birch pollen isoflavone reductase, were not detected.

\section{Conclusion}

Bet v 1 sensitization is associated to concomitant birch pollen rhinoconjunctivitis and oral allergy syndrome to Rosaceae fruits in patients from the Southern Romania sylvosteppe area with low density forests.

\footnotetext{
Authors' details

'University of Medicine and Pharmacy"Carol Davila", Hospital "Nicolae Malaxa", Department of Allergology and Clinical Immunology, Bucharest, Romania. "University of Medicine and Pharmacy"Carol Davila", Hospital"Nicolae Malaxa", Department of Allergology and Clinical Immunology, Bucharest, Romania. ${ }^{3}$ Hospital "Nicolae Malaxa", Department of Allergology and Clinical Immunology, Bucharest, Romania.
} 


\section{doi:10.1186/2045-7022-4-S2-P47}

Cite this article as: Vieru et al:: Sensitisation pattern to birch pollen allergen components in oral allergy syndrome to Rosaceae fruits in patients with spring pollinosis from an East European Sylvosteppe area with low density forests. Clinical and Translational Allergy 2014 4(Suppl 2): P47.

Submit your next manuscript to BioMed Central and take full advantage of:

- Convenient online submission

- Thorough peer review

- No space constraints or color figure charges

- Immediate publication on acceptance

- Inclusion in PubMed, CAS, Scopus and Google Scholar

- Research which is freely available for redistribution 